\title{
VIAJEROS BRITÁNICOS DEL SIGLO XIX ANTE LA FIESTA NACIONAL
}

\author{
Blasina Cantizano Márquez. Universidad de Almería
}

\begin{abstract}
El presente trabajo analiza los comentarios que se realizan sobre la fiesta de los toros en la literatura de viajes británica del siglo XIX, y sugiere que más que un análisis minucioso de la fiesta, para los viajeros el espectáculo taurino era una excusa para indagar en el comportamiento y las actitudes de un pueblo que, debido a sus supuestas actitudes de tosquedad y falta de artificio, era un destino obligado para los viajeros románticos. Los comentarios que aquí se recogen sobre la fiesta nacional pueden servir para considerar las actitudes sociales de los españoles del siglo XIX desde un prisma distinto y original.
\end{abstract}

La Guerra de la Independencia española (1808-1814), junto con el movimiento romántico, fue un factor decisivo de un fenómeno único y característico de la España del siglo XIX: la inusual afluencia de viajeros europeos en busca de ideales románticos como la libertad, la exaltación de los sentimientos y la huella de culturas lejanas. Para los visitantes de la época, el paisaje español, agreste y salvaje, tiene su paralelo en el carácter de sus habitantes, quienes ante los viajeros se muestran naturales y expresivos, se trata de un pueblo que defiende y expresa sus emociones, encarnando y haciendo realidad los ideales del Romanticismo ${ }^{1}$. Uno de los principales atractivos que ofrece nuestro país a los viajeros europeos que lo visitan es el de su espectáculo nacional, las corridas de toros; ya los primeros visitantes británicos de épocas anteriores comentaron el carácter fiero y salvaje de esta diversión española, en la que sangre y arena se unen en un espectáculo sin igual ${ }^{2}$. Durante el siglo XIX, muchos son los británicos que acuden invitados a alguna de las corridas celebradas en las diferentes ciudades que visitan, aprovechando la ocasión no sólo para disfrutar de tan típico espectáculo, sino también para observar de cerca a la población que allí se reúne.

\footnotetext{
${ }^{1}$ Es necesario apuntar que el Romanticismo británico ocupa un período comprendido entre 1798 y 1832 , mientras que este movimiento llega a España de forma tardía, desde finales de la década de los veinte hasta mitad de siglo.

${ }^{2}$ Información detallada sobre los primeros viajeros británicos en España y sus impresiones ante la fiesta nacional española la encontramos en Guerrero, A.: Viajeros Británicos en la España del Siglo XVIII y Krauel Heredia, B.: Viajeros Británicos en Andalucia de Christopher Hervey a Richard Ford (1760-1845).
} 
El presente trabajo nace con la intención de aproximarse a las corridas de toros como espectáculo y fenómeno social: partiendo de la literatura de viajes británica del siglo XIX de tema español se van a exponer las distintas opiniones y consideraciones que de la fiesta nacional española hacen los autores británicos para comprobar así no sólo el grado de fiabilidad de sus relatos a la hora de reconstruir parte de nuestra propia historia, sino también para distinguir las similitudes y diferencias existentes entre los testimonios de autores masculinos y sus compatriotas femeninas, comparando dos perspectivas muy diferentes, a la vez que complementarias entre sí, con las que podremos obtener una visión general, contrastada y muy cercana al ambiente taurino del siglo XIX.

Los viajeros británicos que recorren España durante la Guerra de la Independencia tienen ocasión de comprobar cómo muchas corridas son organizadas en honor de los representantes diplomáticos de su gobierno; así William Jacob asiste a una corrida celebrada en el Puerto de Santa María en noviembre de 1809 en honor del duque de Wellington. El viajero hace su entrada en la plaza justo cuando retiran el primer toro y brindan el siguiente al rey británico Jorge III (Jacob, 1811: 172). Las consideraciones de los viajeros sobre la fiesta nacional van a ser de muy diferente naturaleza, mostrarán la sensación de admiración, indiferencia o repulsión que cause el espectáculo en el observador. En este sentido, podemos establecer una distinción entre los viajeros masculinos, que generalmente muestran una actitud de respeto ante la tradición y la fiesta, y las viajeras, que se muestran contrarias a la crueldad y el derramamiento de sangre. Ejemplo de admiración por la fiesta es el capitán Rochfort Scott, quien disfruta de más de una corrida, defendiendo que no son tan sangrientas, pues en las muchas que ha presenciado sólo ha visto a cuatro hombres heridos, e incluso apunta que «(...) must apologize for having become an aficionado»(Rochfort, 1838: I, 131).

En el otro extremo contamos con el testimonio de la viajera Frances Elliot, quien, aun conociendo el tipo de espectáculo al que va a acudir, tan pronto empieza la corrida se escandaliza por lo que presencia, critica a la sociedad española y termina compadeciendo la suerte del toro, víctima inocente del festejo:

I delight the Spaniards, generally, as a nation, but I abhor them at a bull-fight! Yet no one else seems of my opinion. (Elliot, 1884: II, 195)

Poor brute! With a deep wreath of gore round his neck he gave one woeful look round as who might say, "I am nothing but a poor country bull, come up from the marshes to amuse you. Will no one take pity on me?" None! (Elliot, 1884: II, 201)

All this time I am looking for "the excitement"; I find none. It was a dreary bloody butchery, nor only with the first bull but with a second one, which I forced myself to see. (Elliot, 1884: II, 202)

De la misma opinión es la marquesa de Londonderry, que acude a la plaza con la intención de comprobar la razón de la excitación del público ante las corridas, fiesta que califica de cruel y brutal en los siguientes fragmentos:

There is much interest and excitement in this exhibition; and however great the disgust and horror one may feel at the cruelty and brutally exhibited, it is almost impossible to withdraw one's eye from the scene before them. (Londonderry, 1843: 28) 
On the whole, after the death of the sixth bull, I was glad to come away, rejoining that I had had an opportunity of seeing national amusement, but nor at all desirous of ever witnessing it a second time. (Londonderry, 1843: 29)

Los sentimientos expresados por esta autora en los comentarios anteriores son contradictorios hasta el punto de reflejar una atracción fatal hacia los toros, pues si bien habla de un espectáculo cruel, también le resulta imposible apartar sus ojos de lo que acontece en la arena, hasta el punto de permanecer en la plaza hasta la muerte del último toro, completando así una tarde taurina que asegura no volverá a repetir. Todo parece indicar que la fiesta no resulta tan desagradable a una autora que encarga la miniatura de una corrida de toros para llevarla a Inglaterra como recuerdo de su viaje a España: "They make here some very spirited figures in clay, representing the various national costumes. I desired that a whole bull-fight might be for me and sent to England" (Londonderry, 1843: 62).

En esta disputa encontramos algunos viajeros, mujeres principalmente, que se sienten realmente molestos, incluso seriamente afectados por lo que presencian; como ejemplo ofrecemos la anécdota de la señora Romer en una corrida de toros a la que acude durante su estancia en Málaga, experiencia insoportable que le hace protagonizar un sonado espectáculo entre las damas de su palco; también contamos con las medidas de precaución que toma Frances Elliot antes de iniciarse la faena:

I was utterly unable to control my feelings; and the ladies in the palcos on either side of mine were perfectly scandalized at beholding me cry bitterly over that which afforded such unqualified delight to themselves. (Romer, 1842: II, 176)

I sat by a pretty Spanish lady to whom I offered to all possible civilities, because I knew that as matters procceded nothing could prevent my seizing hold of her in the paroxysm of the moment. (Elliot, 1884: II, 201)

En general, y salvando posturas contrarias como las anteriores, el viajero británico contempla la corrida como una muestra más del carácter, la cultura y la tradición más viva de España; es más, se trata de un acontecimiento muy acorde con la personalidad, la agresividad y la fortaleza que observa en nuestro país. Cuando el viajero británico acude a la plaza por primera vez, para muchos la única, lo primero que le llama la atención es que se trata de un «deporte» nacional, donde acuden gentes de toda edad, sexo y clase social. Como bien apuntan el reverendo Roberts y Hugh Rose, las plazas de toros gozan de numeroso público, suelen estar completamente llenas y es posible ver a gentes de toda condición, incluso a madres que llevan a sus hijos para disfrutar de la corrida:

(...) in Spain, all classes, from the highest to the lowest, men and women alike, take their place at the bull fight, as regularly as at opera or play. (Roberts, 1860: 425)

The seats are nearly all occupied, and by every variety and class of men, not excepting women, who are generally numerous and who seem to have a peculiar pleasure in bringing their children, and especially their babies, to see the sight. (Rose, 1875: I, 371)

Aparece algún autor, sin embargo, que hace distinciones entre unas zonas del país y otras; así, la señora Harvey asegura que en las plazas es más numerosa la presencia de hombres que 
de mujeres y que las corridas suelen ser propias de las provincias más que de la capital, en cuya plaza de toros es poco frecuente ver a mujeres de clase alta:

To the honour of our sex, the number of men largely preponderated. The proportion of women could not have been more than one in ten. (Harvey, 1975: 115)

It is however gratifying to know that amongst ladies of the higher classes the amusement is looked upon with disfavour. In Madrid very few ladies are present, young girls never. (Harvey, 1975: 131)

In the provinces, the old national feeling is stronger, and few fail to attend the first bull-fight of the season. (Harvey, 1975: 132)

Al observar detenidamente al público, la mayoría de los autores hace mención especial de la importante afluencia femenina a las plazas, hecho que parece ser costumbre nacional y que provoca gran disparidad de opiniones entre los observadores foráneos. Así, entre el variado público, T. Roscoe hace referencia a la presencia de delicadas damas; la asistencia al espectáculo en nada afecta a los encantos femeninos de las espectadoras:

(...) the Spanish ladies loved to frequent the favourite spectacle of their country, and applauded the dexterous exploits of the toreadores without the slighlest detriment to their amiable qualities, or the ordinary sympathies and charities of life... Young ladies, old men, people of all ranks and all characters were accustomed to attend these national festivals, -for such they were, and we are told, that however frequently see, they failed to correct the natural timidity and weakness of the ladies, and in no way impaired the sweetness of their manners. (Roscoe, 1838:181-2)

Bien es cierto que, desde que existen, las mujeres son espectadoras habituales de los festivales taurinos: muchas acuden como pasatiempo, algunas por seguir la tradición y otras por verdadera pasión. Normalmente los observadores extranjeros coinciden en que las españolas disfrutan de la fiesta sin ver nada desagradable o cruel en su práctica. John L. Adolphus observa detenidamente al público femenino y describe esta variedad de actitudes:

Custom has the usual effect in taking off the horror of these things; you see coverly matrons, delicate young ladies, and good little girls, looking at them, amused or indifferent, or ennuyées as it may happen, but clearly without the perception that something very disgusting and horrible is going on. (Adolphus, 1858: 148)

La afición femenina a las corridas de toros es, sin embargo, un hecho muy criticado por otros muchos viajeros, quienes ven en esta actitud la muestra de un carácter nada femenino y delicado, sino un claro exponente de la misma crueldad que ya habían observado en el sexo masculino. En este sentido, son numerosos los testimonios nos ofrecen escenas de crueldad y frialdad femeninas observadas durante el espectáculo taurino, como las siguientes apreciaciones de Lord Byron y Sir John Carr:

(...) unusual reception of so delightful a sport to some young ladies, who stared and smiled, and continued their applause as another horse fell bleeding to the ground. (En Churchman, 1909: 147) 
(...) the reader will not be surprised to be told that every Spanish lady is as well acquainted with all the fine points of a bull, as an English one is of those of a lap-dog. (Carr, 1811: 65)

No obstante, a pesar de las críticas anteriores, son frecuentes los autores que defienden la asistencia de la mujer a estos espectáculos como parte de la tradición y costumbre de la tierra que habita. Como ejemplos destacamos las opiniones de Arthur De Capell Brooke, quien asegura haber visto a alguna espectadora volver la cara en los momentos más desagradables de la corrida, o del aficionado Rochfort Scott, que no considera criticable esta afición de las mujeres españolas:

The Spanish ladies have at all times been loudly censured, and not without justice, for encouraging these savage exhibitions by their presence (...) A Spanish lady regards bull-fighting as a mere espectacle, and pays about as little attention to the cruel scenes which are performing below her, as a woman of fashion does at the opera (...) I have frequently seen them turn aside their heads that they might avoid observing them. (De Capell, 1831: II, 36)

I see no greater harm in the Spanish lady's attendance at a bull-fight, than our fair country woman's witnessing such national sports. (Rochfort, 1838: I, 131)

En cualquier caso, las corridas son un acontecimiento público donde la mujer admira y se deja admirar en lo que para muchas de ellas supone una ocasión más para conseguir admirador o pretendiente. Leonard Williams nos ofrece el siguiente ejemplo, en el que asegura que las jóvenes muestran más interés en coquetear con el público masculino que en admirar a los toreros:

Numbers of the marriageable maidens who attend it care but little for the dexterity and even the valour of the brave toreros, but at least the plaza is as likely a place as any to light upon a novio -and who can even anticipate the wedded state without contentment! Therefore, oh dark-eyed damsels of the South, flirting your fans with so intuitive and pretty a grace, and exhibiting (of course by accident) those tiniest piececitos, when were your smiles more sunny or more inviting to companionship even though it were livelong- than on this dia de toros! (Williams, 1902: 179-180)

Albert F. Calvert comparte esta opinión y asegura que las mujeres no disfrutan de los toros y que lo que verdaderamente las atrae a la plaza no es el espectáculo, sino la hombría y el valor de los toreros, tal como parece observar en una corrida celebrada en Málaga:

It must, however, be noted that a large proportion -certainly the majority of Spanish ladies- are opposed to the sport, and with the rest it is the manly courage and address of the performers that fascinates them. But the fact remains that women are seen in large numbers in the amphitheatre. (Calvert, 1903: 222)

Llegados a este punto es necesario recurrir a la opinión de Richard Ford, uno de los mayores expertos británicos de esa época sobre España y sus costumbres, quien no sólo participa en esta defensa, sino que rechaza toda crítica vertida sobre la presencia femenina en 
los ruedos, asegurando que muchas son las mujeres que acuden a otros espectáculos más sangrientos y desagradables en otras partes del mundo sin que se levante una sola voz en su contra. Ford acierta a comprender que se trata de una forma de diversión en la que las mujeres participan de la mejor manera posible:

Spanish women, against whom every puny escribler darts his petty banderilla (...) The women of the many, as a body, behave quite on respectably as those of other countries do at executions, or other dreadful scenes, where they crowd with their babies, yearning after strange excitement. (Ford, 1845: I, 185)

De hecho, la siguiente anécdota de Williams demuestra que la Fiesta Nacional no sólo atrae a la mujer española, sino que de forma habitual alguna remilgada dama extranjera acude a estos espectáculos en más de una ocasión, como ocurre con la esposa de un capitán inglés al que conoce en Gibraltar:

It was during Algeciras fair (...) that I asked the English wife of an English army captain how she had relished that afternoon's corrida. «Oh, it is dreadful», she replied, «horrible"; but (with a gleam of pleasurable anticipation) «I'm going again tomorrow.» (Williams, 1902: 224)

A lo largo de estas páginas hemos comprobado la afición o repulsión que muestran distintos viajeros ante el espectáculo que toros y toreros ofrecen en el ruedo; para algunos, a las mujeres especialmente, resulta demasiado cruel y sangriento, para los que disfrutan de ella es sólo una fiesta propia de este país y sus gentes. De una forma u otra, observamos que cuando los escritores emiten opiniones críticas sobre la fiesta de los toros, éstas no suelen ir dirigidas al espectáculo en sí, sino contra la presencia del público femenino en la plaza, hecho que parece escandalizar a muchos de los británicos que acuden a los ruedos.

Con aportaciones como éstas de la literatura de viajes británica se puede obtener una visión muy aproximada de lo que era y suponía la fiesta nacional para los españoles de hace doscientos años. Por otra parte, estas opiniones pueden servir como punto de partida para el análisis del clima cultural y de las actitudes morales de esta sociedad determinada. Son ideas , en definitiva, sobre lo permitido y lo rechazado, lo apropiado y lo inaceptable. La perspectiva, diferente y original, de los observadores británicos puede servir por tanto para reconstruir y completar parte importante de nuestro propio pasado.

\section{BIBLIOGRAFÍA}

\section{Fuentes primarias:}

Adolphus , J. L. 1858. Letters from Spain in 1856 and 1857. Londres: Murray.

Calvert, A. F. 1903. Impressions of Spain. Londres: George Philip and Son Ltd.

Carr, J. 1811. Descriptive Travels in the Southern and Eastern Parts of Spain and the Balearic Islands in the Year 1809. Londres: Sherwood.

Churchman, P. 1909. "Lord Byron's experiences in the Spanish Peninsula in 1809" Bulletin Hispanique XI-XII: 125-171.

De Capell Brooke, A. 1831. Sketches in Spain and Morocco. 2 vol. Londres: Colburn and Bentley.

Odisea, $\mathrm{n}^{0} 1,2001$ 
Elliot, F. 1884. Diary of an Iddle Woman in Spain. 2 vol. Leipzig: Bernhard Tauchnitz.

Ford, R. 1845. A Handbook for Travelers in Spain and Readers at Home. 2 vols. Londres: Murray.

Harvey, M. 1975 (2nd ed). Cositas Españolas or Everyday Life in Spain. Londres: Hurst and Blakett Publishers.

Jacob, W. 1811. Travels in the South of Spain in Letters Written a.d. in 1809 and 1810. Londres: Johnson and Co.

Londonderry, M. 1843. A Journal of Three Month's Tour in Portugal, Spain, Africa by the Marchionness of Londonderry. Londres: Mitchell and Co.

Roberts, R. 1860. An Autumn Tour in Spain in 1859. Londres: Saunders, Otley and Co.

Rochfort Scott, C. 1838. Excursions in the Mountains of Ronda and Granada with Characteristic Sketches of the Inhabitants of the South of Spain. 2 vol. Londres: Henry Colburn.

Romer, E. 1842. The Rhone, the Darro and the Guadalquivir. A Summer Ramble in 1842. 2 vol. Londres: John Bentley.

Roscoe, T. 1838. The Tourist in Spain. Andalucia. Londres: Robert Jennings \& Co.

Rose, H. J. 1875. Untrodden Spain and Her Black Country, Being Sketches of the Life and Character of the Spaniard of the Interior. 2 vol. Londres: Samuel Tinsley.

Williams, L. 1902. The Land of the Dons. Londres: Cassell and Company Ltd.

\section{Fuentes secundarias}

Bernal Rodríguez, M. 1985. La Andalucía de los Libros de Viajes del Siglo XIX. Sevilla: Editoriales Andaluzas Unidas.

Díaz López, J.A. 1995. “Apuntes para una historia de las relaciones literarias hispanobritánicas en el siglo XIX". Estudios de Literatura Inglesa. Granada: Servicio de Publicaciones de la Universidad. 9-53.

Guerrero, A. C. 1990. Viajeros Británicos en la España del Siglo XVIII. Madrid: Aguilar.

Krauel Heredia, B. 1990. Viajeros Británicos en Andalucía de Christopher Hervey a Richard Ford (1760-1845). Málaga: Servicio de Publicaciones de la Universidad. 